\title{
Traditional dairy products in Algeria: case of Klila cheese
}

\author{
Choubaila Leksir ${ }^{1}$, Sofiane Boudalia ${ }^{1,2^{*}}$ (D) Nizar Moujahed ${ }^{3}$ and Mabrouk Chemmam ${ }^{1,2}$
}

\begin{abstract}
The cheese Klila occupies a very important socio-economic place established in the rural and peri-urban environment. It is a fermented cheese produced empirically in several regions of Algeria. It is the most popular traditional cheese and its artisanal manufacturing process is still in use today. The processing consists of moderate heating of "Lben" (described a little farther) until it becomes curdled, and then drained in muslin. The cheese obtained is consumed as it stands, fresh, or after drying. When dried, it is used as an ingredient after its rehydration in traditional culinary preparations.

In this review, we expose the main categories of traditional Algerian dairy products; we focus mainly on the traditional Klila cheese, its history, origin, and different manufacturing stages. We recall the different consumption modes and incorporation of Klila cheese in the culinary preparations.
\end{abstract}

Keywords: Traditional cheese, Klila, Terroir

\section{Introduction}

In Algeria, the consumption of dairy products is an old tradition linked to livestock farming, since dairy products are made by means of ancient artisanal processes, using milk or mixtures of milk from different species [1-4]. There is a wide variety of artisanal dairy products (from the "terroir" in French), their denomination as well as their manufacturing process differing from one region to another. These products also differ in their taste and their consistency.

"Klila" is a fermented cheese produced empirically in several regions of Algeria. It is the most popular traditional cheese and its artisanal manufacturing process is still in use today [4-6]. The processing consists of moderate heating of "Lben" (described a little farther) until it becomes curdled, and then drained in muslin. The cheese obtained is consumed as it stands, fresh, or after drying. When dried, it is used as an ingredient after its rehydration in traditional culinary preparations $[7,8]$.

\footnotetext{
*Correspondence: sofiane.boudalia@hotmail.com; boudalia.sofiane@univguelma.dz

${ }^{1}$ Faculté des Sciences de la Nature et de la Vie et Sciences de la Terre et de I'Univers, Université 8 Mai 1945 Guelma, BP 4010, 24000 Guelma, Algeria ${ }^{2}$ Laboratoire de Biologie, Eau et Environnement, Université 8 Mai 1945 Guelma, BP 4010, 24000 Guelma, Algeria

Full list of author information is available at the end of the article
}

\section{Traditional dairy products in Algeria}

\section{History and origin of cheeses}

According to Fox and McSweeney [9], the word "cheese" comes from the Latin "formaticus" meaning "what is done in a form." The discovery of cheese was probably by chance, of unknown precise origin, but archaeological discoveries indicated that cheese is made from the beginning of breeding. The first traces of dairy farming date back to 10,000 years in the Middle East. Sheep and goat milks were apparently the first processed milks, and sheep and goats have been the first domesticated animals [10].

The discovery of utensils and containers used in cheese making during the numerous archaeological excavations that took place around the world, and in particular in Egypt, Mesopotamia, or in the Mediterranean basin, has given evidence of the very ancient use of these fermentations. Cheese was already a popular food item during the Greek and Egyptian eras [11]. It is thanks to the Romans that the art of making different types of cheese was developed [9]. Cheese making is the oldest known way of preserving milk [12-14]. Man has noticed that the milk he was storing coagulated and that once it is separated from its serum (whey), the coagulum becomes a compact mass that could dry and thus be preserved and transported [10, 15]. The spontaneous

(c) The Author(s). 2019 Open Access This article is distributed under the terms of the Creative Commons Attribution 4.0 International License (http://creativecommons.org/licenses/by/4.0/), which permits unrestricted use, distribution, and 
acidification is causing the coagulation and giving rise, because of its slowness, to the cream on the surface; fermented milks, butter, and dry cheese were probably the first dairy products.

\section{Algerian traditional dairy products}

Contrary to popular belief, Algeria does have wellestablished traditions of manufacturing dairy products even if the activity is limited to the domestic sphere. The traditional dairy products, with strong cultural, medicinal, and economic value, are the historical product of the social and economic dynamism of the rural communities of women [16]. Despite their anchoring in the Algerian culinary tradition and their ability to exploit the natural resources of disadvantaged regions (animal and plant species of mountain and Saharan ecosystems), these products evolve on the margins of implemented development policies in Algeria. The great majority of them are being downgraded by the markets through the emergence of dairy processing industries oriented more towards the satisfaction of the major urban markets, in subsidized milk and dairy products, than towards the valuation of local milk production [17].

Many traditional products are vanishing for various reasons, including lack of feed availability, rural exodus, and changing dietary habits. Those ones, whose use is most widespread, such as Rayeb and Jben, and while keeping the same name, have changed their technological process because of their industrialization $[18,19]$.
Main categories of Algerian traditional dairy products The different types of Algerian traditional dairy products are shown in Fig. 1.

\section{Fat dairy derivatives}

\section{Zebda (butter)}

"Zebda" or fresh butter is obtained after churning "Rayeb." The latter is added by a quantity of warm water $\left(40-50^{\circ} \mathrm{C}\right)$ at the end of shaking to promote the agglomeration of fat globules and increase the yield of butter. Lipid globules appear on the surface and are recovered at the end of churn $[20,21]$. The fresh butter obtained has a soft consistency due to the high concentration of water [19]. It is also made in Middle Eastern countries and is known as Zobdeh [22].

\section{Smen}

The surplus of butter produced is transformed into rancid butter "Smen" by washing the fresh butter with warm water, brining, then dry salting (dusting on the surface, $8-10 \mathrm{~g} / 100 \mathrm{~g}$ ) [18]. Smen is a fatty milk derivative popular in the Maghreb countries, notably Algeria [21] and Morocco [23].

\section{Shmen (Semma)}

"Shmen" or "Semma" is clarified butter oil obtained by churning spontaneously acidified camel milk [22]. The butter is then boiled and clarified after the addition of a clarifying agent (for example, crushed dates) and
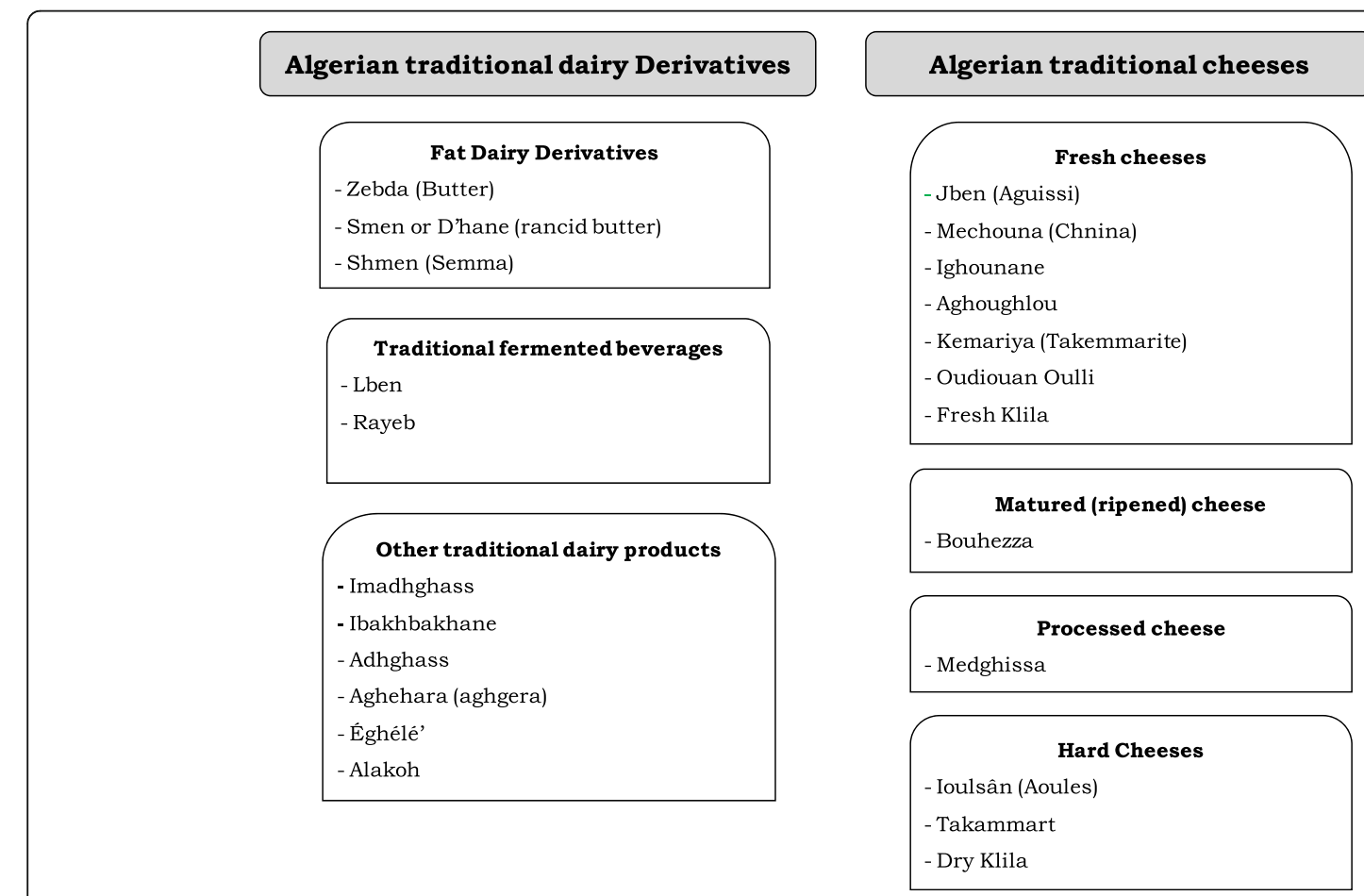

Fig. 1 Algerian traditional dairy products 
skimming after flocculation of the impurities. It is used by the Tuaregs (Algerian Sahara people) for the preparation of food or for cosmetic purposes [24].

\section{Traditional fermented beverages \\ Raib}

"Raib" is a fermented milk produced in many Mediterranean and sub-Saharan countries [25]. "Raib" is curdled milk, traditionally obtained after spontaneous acidification at room temperature of raw milk during a period ranging from 24 to $72 \mathrm{~h}$; it is consumed as it is or transformed. Fermentation has been associated with mesophilic lactic acid bacteria belonging to the genera Leuconostoc and Lactococcus naturally present in raw milks $[18,26]$.

\section{Lben}

"Lben" is one of the best-known products of artisanal milk processing; it is prepared following the churning of "Raib" and butter separation [27]. Churning makes it possible to collect the majority of its fat in the form of butter called "Zebda." The homemade or family preparation of "Lben" is simple: the milk is left to itself in a "Rawaba" terracotta pot until it coagulates [21, 22, 28]. This is done at room temperature and lasts 24 to $72 \mathrm{~h}[23,29]$.

The gel formed is stirred by a spoon or a ladle to facilitate his transferring in the container used for churning or "Makhda." Since ancient times, three types of traditional churns, varying from one region to another, are used in Algeria. Chaouias and Saharan nomads used the "Chekoua" (Fig. 2). It comes from a laborious treatment of goat skin or sheep skin. The "Chekoua" filled with "Raib" is suspended to a tripod or a beam and vigorously agitated from front to back until the coalescence of aggregates of fat particles. The fat particles then agglomerate together, to form grains of butter [18, 21, 26, 30]. In the region of Eastern Kabylie (K'bayel el Hedra) Ferdjioua, Mila, and Jijel, women used terracotta utensils called "Mezla" or "Artoul" when it came to small volumes (Fig. 3).

On Djurdjura, Kabyle (other regions in the North of Algeria) women use "Thakhssayeth Oussendou" also called "Thakhchachet" (Fig. 4). This choice was not made at random; on the mountainous and rigid soil of Kabylie grow trees and plants including the calabash. This slightly exotic fruit, rigid and empty from the inside, serves as a traditional churn in Kabylie. The manipulator must shake vigorously, and then add small amounts of hot or cold water depending on the ambient temperature, so as to bring the temperature of the set to a level suitable for collecting the grains of butter. The churning operation lasts $40 \mathrm{~min}$ until $1 \mathrm{~h}$ and $15 \mathrm{~min}$. "Zebda" is collected, usually by hand [21, 23].

Currently, "Lben" is currently manufactured industrially [27], and this dairy product remains largely manufactured nowadays by craftsmen according to its traditional process

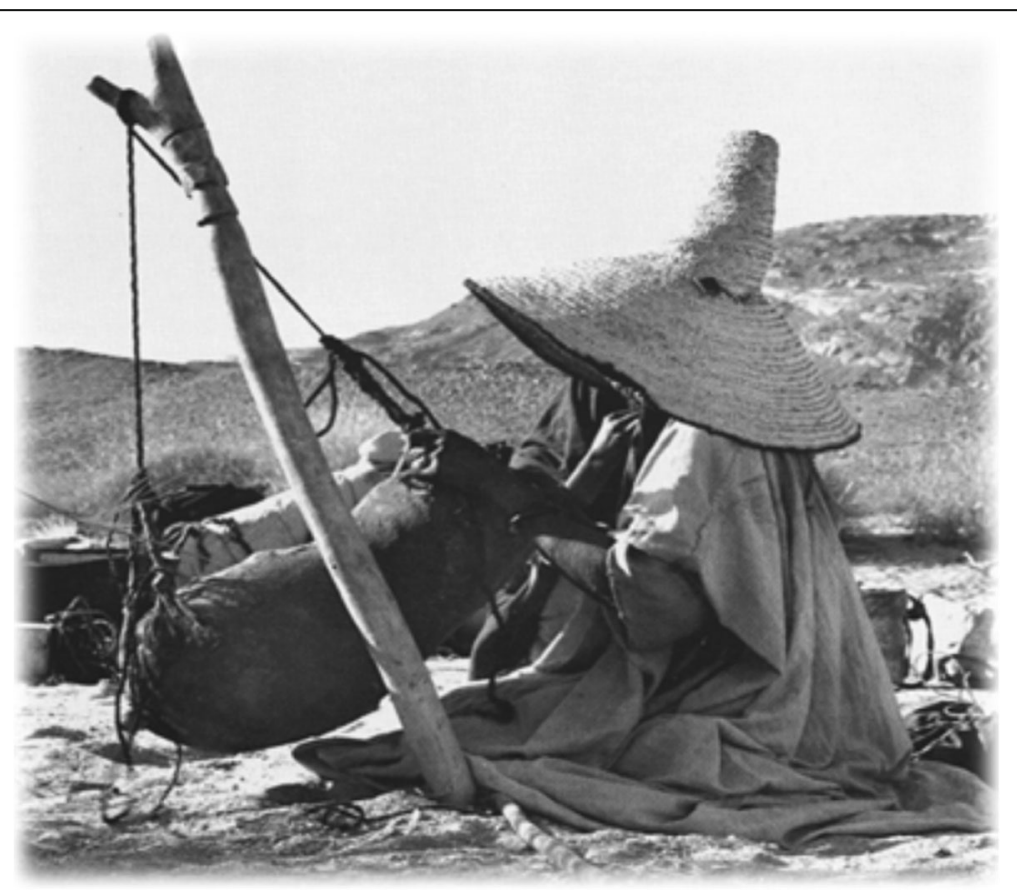

Fig. 2 "Chekoua": goatskin or sheepskin churns: used by Chaouias and Saharan nomads. The "Chekoua" filled with "Raib" is suspended to a tripod or a beam and vigorously agitated from front to back until coalescence of aggregates of fat particles. The fat particles then agglomerate together, to form grains of butter [21] 


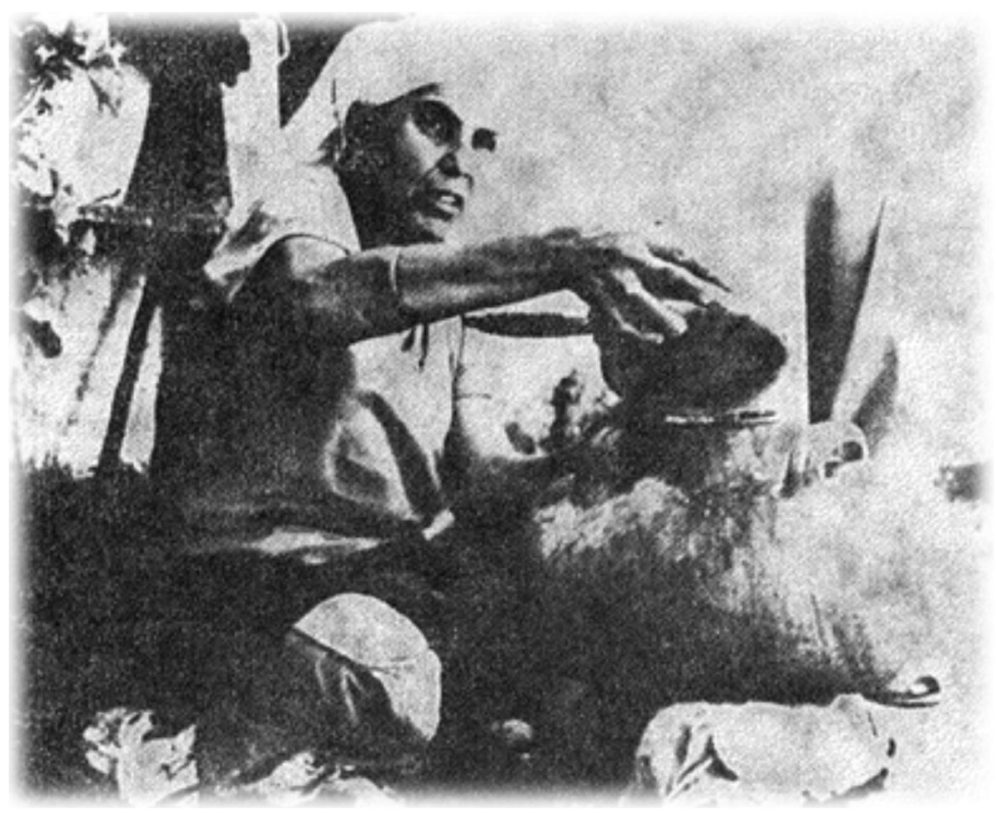

Fig. 3 "Mezla": terracotta churns. In the region of Eastern Kabylie (K'bayel el Hedra) Ferdjioua, Mila, and Jijel (northeastern regions of Algeria), women used terracotta utensils called "Mezla" when it came to small volumes. The "Mezla" is placed on a piece of cork and shaken to extract the butter. On the side of the "Mezla" is a small hole that is closed with a cloth called "Anfous" that women remove from time to time during churning to evacuate the air forming inside the churn. The orifice of the churn is sealed with a piece of goatskin called "Afazaz" wrapped around the main opening of the churn by a string [31]

in the Maghreb countries, notably in Algeria, in Tunisia craftsmen [32], as well as in Morocco [33]. "Lben" is the basic ingredient for making the traditional Klila cheese.

\section{Algerian traditional cheeses}

Cheese is the largest and most diverse group of dairy products. Their artisanal production is strongly linked to the "terroir" [17]. Traditional cheeses are cultural goods that deserve to be studied, characterized, and protected $[28,34]$. Some cheeses are known, made, and eaten to the present day, while others are unfortunately endangered for various reasons, namely the unavailability of fodder, the rural exodus, and the change in food habits. Traditional Algerian cheeses are distributed into four main categories, namely fresh cheeses, ripened cheeses, processed cheeses, and hard cheeses.

\section{Fresh cheeses \\ Jben (Aguissi)}

Jben is traditionally made in the Maghreb countries; denomination gathers very different technological trajectories, resulting in products with very varied characteristics $[17,18]$. A stage of spontaneous acidification can usually occur at ambient atmosphere, during $24 \mathrm{~h}$ to $72 \mathrm{~h}$ depending on the temperature. "Jben" cheese is made with raw sheep milk or goat milk, spontaneously acidified and coagulated by coagulating enzymes of plant origin from cardoon flowers (Cynara cardunculus L.), a wild thorny plant (Cynara humilis), artichoke (Cynara scolymus), or pumpkin seeds [35]. The whole flowers are macerated in the milk. The plant is used to accelerate the coagulation and to give a taste to the cheese. The plant variety used varies from one region to another; it gives a taste and a texture appreciated by the people of the concerned region. The curd is then drained and salted or not, according to the tastes.

As described Benkerroum and Tamime [18], the "Jben" in Morocco can be hand made without enzymatic coagulation; in this case, raw milk is only coagulated by spontaneous acidification, and then the curd is drained for 2 to 3 days to obtain the desired consistency. Additives can be added after draining and salting (garlic, parsley, pepper, etc.). The cheese obtained in other Arab countries corresponds to cheese named "Jibneh Beida" [22].

Finally, a third technological process, using animal rennet, cow milk, and acidifying starters, is industrially used. Depending on the region, the "Jben" may be salted and then drained for 10 days, or unsalted and drained for less than 4 days, with an average of $62.5 \%$ moisture, $16.5 \%$ fat, $15.8 \%$ crude protein, $4.1 \%$ lactose, $1.04 \%$ titratable acidity, and $\mathrm{pH} 4.1$ [36].

\section{Ighounane}

Ighounane is cheese made in the heights of Djurdjura in Kabylie from colostrum (the first milk of cow giving birth); the "Ighounane" preparation is made in terracotta 


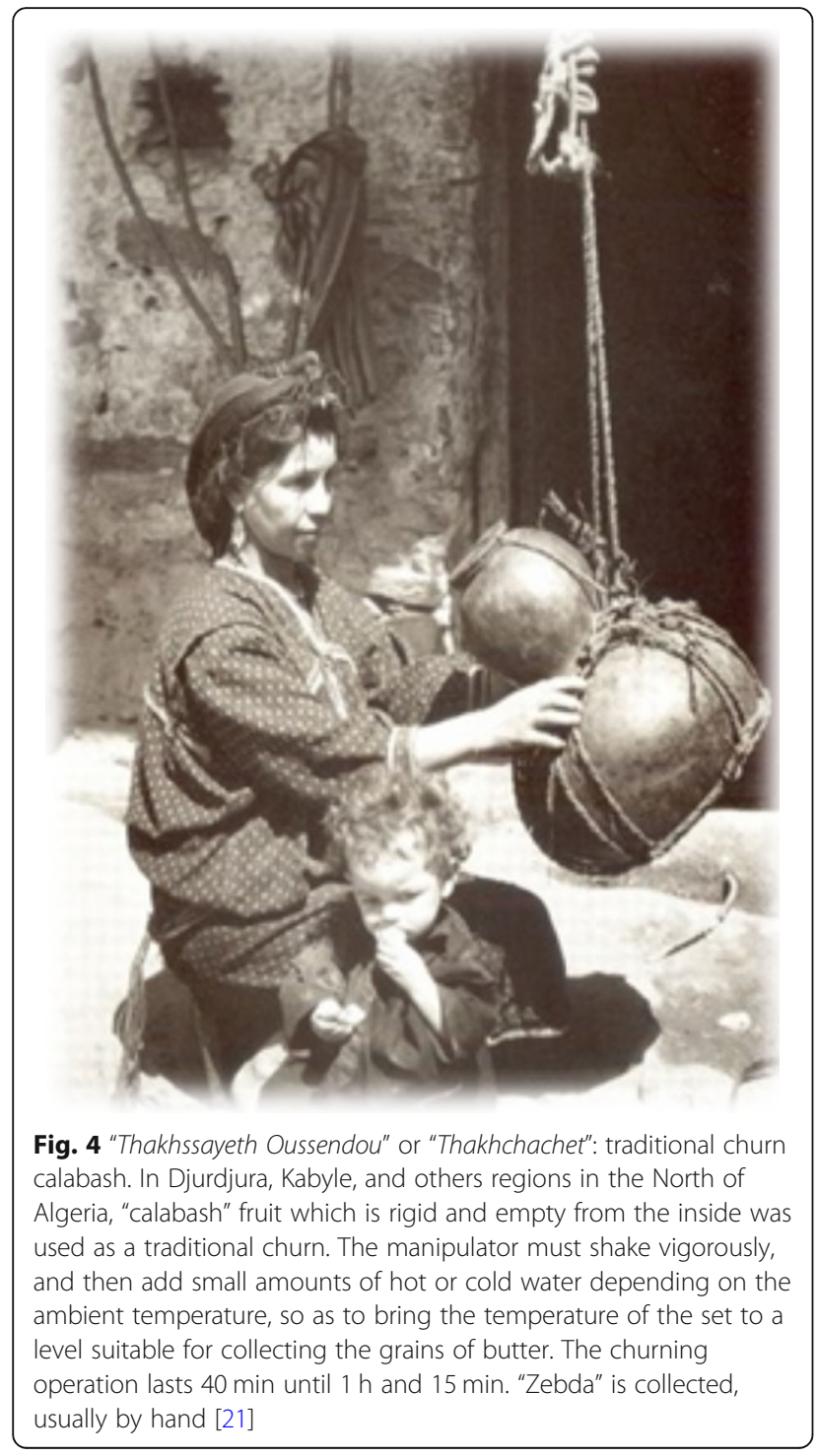

utensils coated with olive oil into which a small amount of salted water is poured, and then the milk is heated and coagulated. The curd formed is cut to continue draining and then is consumed as it is.

\section{Aghoughlou}

Aghoughlou is cheese made in Kabylie, obtained from fresh cow or goat milk coagulated by the fig tree latex (Ficus carica). The curd obtained is eaten fresh.

\section{Mechouna (Chnina)}

"Mechouna" is a cheese traditionally prepared with goat or cow milk. It can be considered as a fresh soft cheese. The process begins with heat treatment of the milk to boiling. Then, "Lben" is added with salt; the amount of "Lben" is half that of milk. The whole is heated a second time until coagulation and separation of curd and whey.
The curd is separated from the whey by filtration, first through a kitchen sieve and into a fine fabric (muslin), and then suspended and allowed to drain until complete the elimination of the whey. Generally, this step can last overnight to ensure that the drip is complete, then the pressing is done [37]. The cheese is obtained back and kept in cool glass containers. The preservation of this cheese must not exceed 6 days. In order to improve its organoleptic qualities, this cheese can be added with several spices according to the choice of the consumers; in such a state, the "Mechouna" is called "Chnina" [37].

\section{Kemariya (Takemmarite)}

It is a traditional cheese made only from goat milk, and it is made by women according to traditional methods in the regions of "M'zab" [17] especially in the wilayates (districts) of Ghardaia and Naama (northern central and northern west of Algeria). "Kemariya" is a cheese that is often eaten as a dessert during the festive seasons with honey, peanuts, and served with mint tea. It is coagulated by vegetable or animal rennet and is also made from cow and camel milk. Due to the high demand for this cheese, it is increasingly produced by small factories in semi-industrial processes to be sold both in traditional markets and in some supermarkets of northern Algeria [17].

\section{Oudiouan Oulli}

It is a Tuareg cheese similar to cottage cheese served in small portions and eaten fresh or dried.

\section{Fresh Klila}

To avoid degradation during the storage phase, "Lben" is heated moderately $\left(55-75^{\circ} \mathrm{C}\right)$ until whey is separated; the coagulum obtained, called "Klila," made in several regions of Algeria, is consumed as a fresh cheese after natural draining $[4-6,38]$.

\section{Hard cheeses \\ loulsân (Aoules)}

Ioulsân is a traditional Algerian cheese prepared by the Tuaregs of Hoggar or Ihaggarren (people from Algerian Sahara). It is a typical dry cheese ( 87 to $92 \%$ of dry matter), obtained by the moderate heating of the skimmed "Lben" coming from goat milk coagulated spontaneously. It is a fresh cheese, rarely ripened, with acid addition and heating of buttermilk, and it has a great resemblance to "Skyr" (Iceland), "Karish" (Egypt), and "Quark" (Germany) [17]. The heating is done in a clay container until the precipitation of the caseins. The precipitate is stretched in a basket of straw, and the curd is mixed in small quantities to form a small flat cylinder (2-cm thick, 6 to $8 \mathrm{~cm}$ in diameter) [22]. The cheese is then sun-dried, crushed, and can be mixed with date paste or with beverages [19]. 


\section{Takammart}

Literally "cheese" in the "Tamasheq" (Tuareg) language, "Takemmart" is a cheese from the Hoggar desert region (from Tamanrasset province in southern of Algeria), produced by the introduction of a piece of "abomasums" of young goats in the milk. The curd obtained is removed using a ladle and deposited and kneaded on mats containing fennel stems giving it a particular taste. The mats are subsequently exposed to the sun for 2 days and then placed in the shade until the cheese hardens $[17,39]$.

\section{Dry Klila (dehydrated)}

As it can be eaten fresh, "Klila" cheese can also be cut and dried ( 2 to 15 days depending on the season) and then used after rehydration as an ingredient in culinary preparations. In its dehydrated form, it can be kept for several years at room temperature, in terracotta jars or goatskin bags [5, 40].

\section{Bouhezza matured cheese}

This is a traditional, soft-ripened cheese from the eastern regions of Algeria (Oum El Bouaghi, Khenchela, Batna...) once famous because of an important practice of extensive goat and sheep farming. Originally, "Bouhezza" was traditionally the product of the processing of goat milk and ewes, but the current trend seems to be towards the use of cow milk [25, 41-44].

The cheese is obtained after the transformation of the "Lben" in a "skinbag" or a "Chekoua" made of goatskin previously treated with salt and juniper [41]. Draining, salting, and refining "Bouhezza" are performed simultaneously in the "Chekoua" for a period of 2 to 3 months. During the ripening period, "Lben" and milk are added to the contents of the "Chekoua." At the consumption stage, the cheese is kneaded with the adjunction of red pepper powder, which gives it a particular characteristic [41].

\section{Processed cheese Imdeghest (Medghissa)}

"Imdeghest" or "Medghissa" is a processed cheese from the Chaouia region (Northeastern of Algeria), prepared by cooking semi-dry "Klila" in whole milk from cow, goat, or sheep, over low heat. "Medeghissa" is consumed as a snack and appreciated for its elasticity [45].

\section{Global diagram of traditional Algerian cheeses}

Figure 5 illustrates the production processes of the main Algerian dairy and cheese products.

\section{Traditional Algerian cheese "Klila"}

\section{History of the "Klila" cheese study}

Men proceeded to milk mammals; it is probably during the attempts to store the surplus milk that appeared the first curds that will later become cheese. Since then, people, as well as nations, have not stopped furthering the process. Not claiming a paternity of cheese in any case, nations codify, regulate, and protect their cheese specialities. In Algeria, there are several varieties of traditional cheeses, including "Klila."

Craft production of "Klila" cheese is a traditional way of perpetuating an ancestral know-how and preserving the culinary heritage of intensive cattle, goat, and sheep breeding regions that characterized, long ago, the region of eastern Algeria. "Klila" cheese, made from the processing of milk during high lactation periods, was always present on the menus of all families, especially in spring.

"Klila" cheese was for a long time the only way to preserve milk. In spring, when the grass is high enough to feed the livestock and give a good milk production, the raw milk is left to itself, at room temperature, until its spontaneous coagulation. It is then churned to get the "Lben," which is poorly preserved as it quickly becomes embittered after 2 to 3 days. To avoid waste, the product that is not consumed in case of overproduction is heated to separate the whey and curd, and it is this curd that is called "Klila." It is then consumed as dried or fresh cheese and incorporated into various culinary preparations [4].

Considered as products with "high cultural and economic value," traditional dairy products, "Klila" cheese, in particular, are "a sign of the social and economic dynamism of rural women communities." "Klila" can be dried to harden like a stone [40]. Crushed, it is used as a condiment in the cooking of the nomads who also consume it when on a trip by letting it melt under their tongue. "Klila" cheese, although well known, manufactured, and consumed in Algeria since the dawn of time $[21,46,47]$ until today in quite a few regions in Algeria, it has unfortunately been very little studied.

\section{Origin of denominations}

The name of "Klila" cheese has been used since ancient times by the autochthonous Berbers of Algeria [4, 46]. It comes very probably from the Berber word "Ikil" which means curdled milk. Among the "Chaouis" people (Berber population inhabiting the regions located in and surrounded by the Aurès Mountains, Algeria), when the milk curdles, they say "T'kellel." In Kabylie, the milk that curdles spontaneously in hot weather is called "Tiklitt" and as the traditional "Klila" cheese is the curd recovered after fermentation and curdling milk. It remains one of the strongest assumptions.

Another hypothesis suggests that "Klila" is so called because of the small cheese yield compared to the initial amount of milk used (about 1/10). "Klila," in Arabic "قاليلة" means small quantity.

Currently, it is called "Lagta" in some areas of the far northeastern of Algeria. Formerly, Berbers called "Lagat" a low-fat cheese made and dried under the sun's rays [21]. The word "Lagta" means that in order to obtain this cheese, you have to collect and recover small 


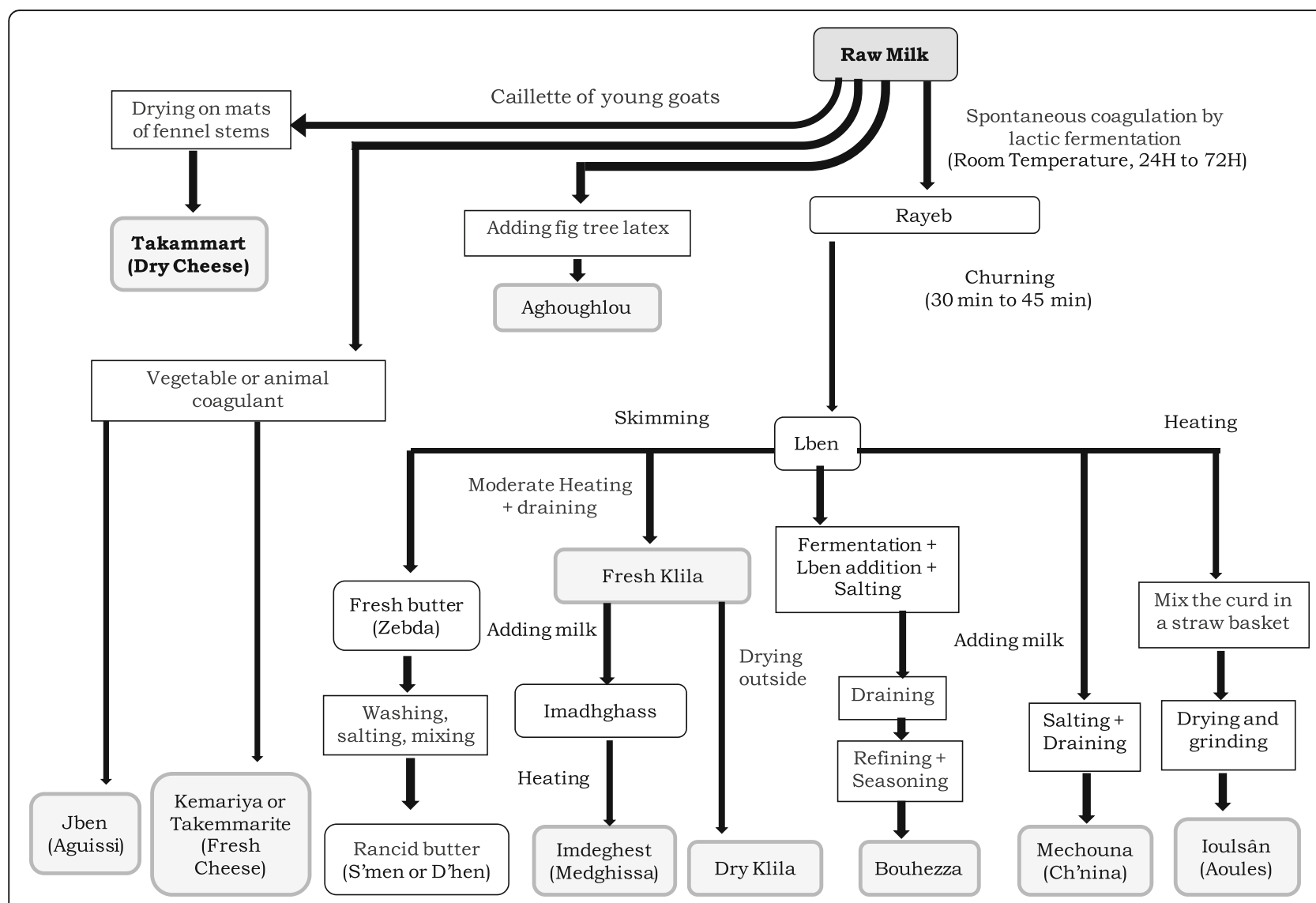

Fig. 5 Illustrative global diagram of the manufacturing processes of the main Algerian dairy products and traditional cheeses

quantities of raw material over several days. In some areas of Algeria, it was referred to as "Lemjeben" which was also sun-dried and added in broths [21]. These data require confirmation by historians specialized in the history of indigenous Berbers and North African nomads.

\section{"Terroir" of traditional cheeses \\ "Terroir" concept}

Traditional cheeses enjoy a special place among various food preparations. Their manufacturing tradition encompasses not only the know-how of the different generations but also an intimate marriage between the environment and dairy animals, hence the need to preserve this tradition in its natural atmosphere. Each traditional cheese comes from complex systems that give it specific organoleptic characteristics. The notion of "Terroir" for milk and cheese is a geographical area characterized by environmental conditions and types of animals that, when exploited by humans, lead to specific products [48].

The different elements which establish the typicality of each cheese are related to various biodiversity factors, such as the environment, the climate, natural grassland, the breed of animals, the use of raw milk and its natural microflora, the cheese technology based on the unique expertise of men and not on automated technology, historical tools, and finally the natural conditions of ripening.

\section{"Terroir" of traditional "Klila" cheese}

Geographical delimitation of the "terroir" of traditional "Klila" cheese has confirmed the production and consumption of the latter in different regions of eastern Algeria. The area extends over several Wilayas (provinces): Guelma, Souk-Ahras, Oum El Bouaghi, Batna, and Khenchela [4]. Continuing investigations on this cheese have shown that it is known, manufactured, and consumed also in the provinces of Biskra, Tebessa, M'sila, Setif, Bordj Bouarriridj, Taref, and Mila. The families that make this cheese are essentially indigenous Berbers.

From studies of Guetouache and Guessas [8] and that of Benamara et al. [5], they also mentioned the regions of Djelfa and Nama. Benlahcen [6] as well as the provinces of Tiaret, Sidi Belabbes, and El Bayadh (Fig. 6). "Klila" cheese is also produced in Morocco [19, 33]. 


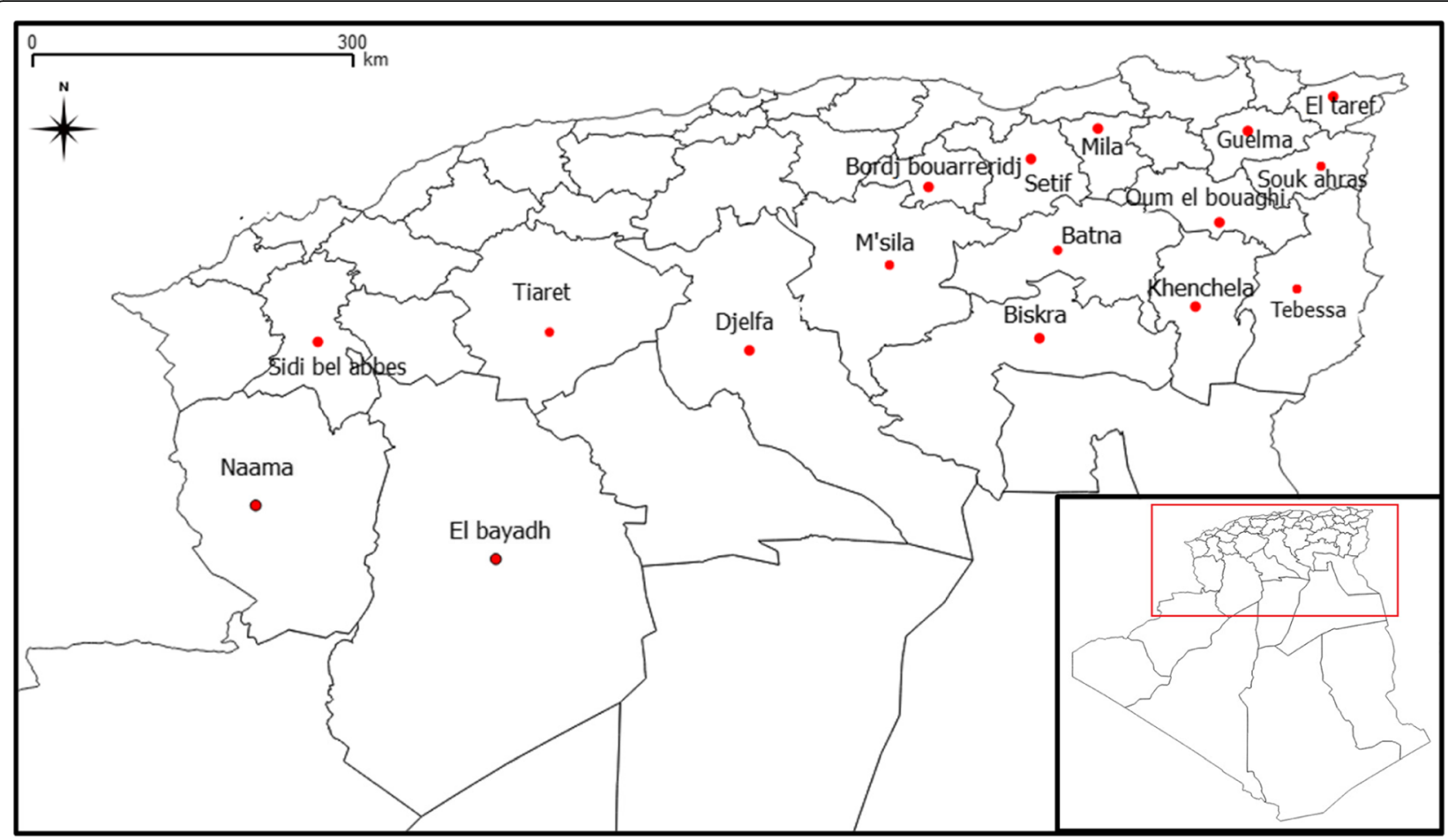

Fig. 6 Geographical delimitation of the "terroir" of traditional "Klila." The area extends over several Wilayas (provinces) essentially in the eastern region of Algeria

\section{Artisanal manufacturing of traditional "Klila" cheese} In rural areas, milk is abundant during periods of high lactation. For lack of means of preservation, it is difficult to keep the excess of this quickly perishable food; the main part of the production is therefore transformed into cheese. In spring, which corresponds to the period of high lactation and milk abundance, milk is collected in milking vases (Fig. 7) and kept in a curdling vase "Rawaba" (Fig. 8). In the absence of a means of

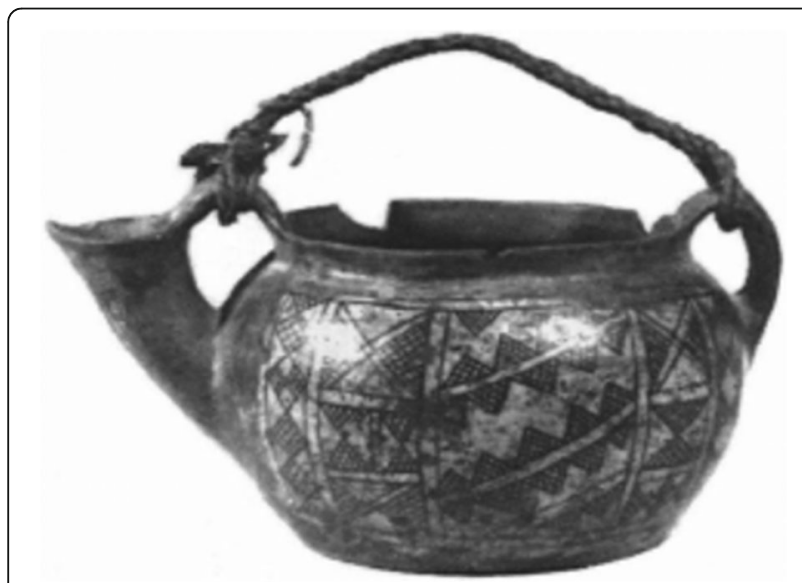

Fig. 7 Milking vase: used to collect milk during the period of high lactation and milk abundance in spring [21] preservation, milk quickly embitters and turns into "Rayeb." This remains the only way to recover it while avoiding any waste $[21,40]$.

The "Rayeb" is then churned in goatskins or sheep skins called "Chekoua." It is churned by adding a little cold water that freezes the butter. It is quite an art to grab the butter: the Berber woman engages her entire arm inside the skin bag put on the ground. She exerts a series of pressures from the bottom up which have the effect of getting the clots of butter in suspension to the orifice where she seizes them. The skimmed milk curd gives an "Lben" extremely prized by the Berbers an acidified and refreshing drink that they gladly take with couscous.

"Klila," as mentioned above, is a fermented cheese produced empirically in several regions of Algeria. Leksir and Chemmam describe "Klila" as the product obtained after curdling of milk. The curd is then churned, cooked, and squeezed lightly. It is eaten fresh or dry. This product was traded by the Saharan Nomad tribes in the Tell markets [4]. However, for the feeding of caravans, goat cheese, dry and hard as stones, were produced. In some tribes, they crush and mix it with cereal flour, all diluted with milk or water [21].

"Klila" cheese is obtained by a relatively moderate heating of "Lben" until the curd and the separation of a clear greenish-yellow whey, "El mis." The curd is drained 


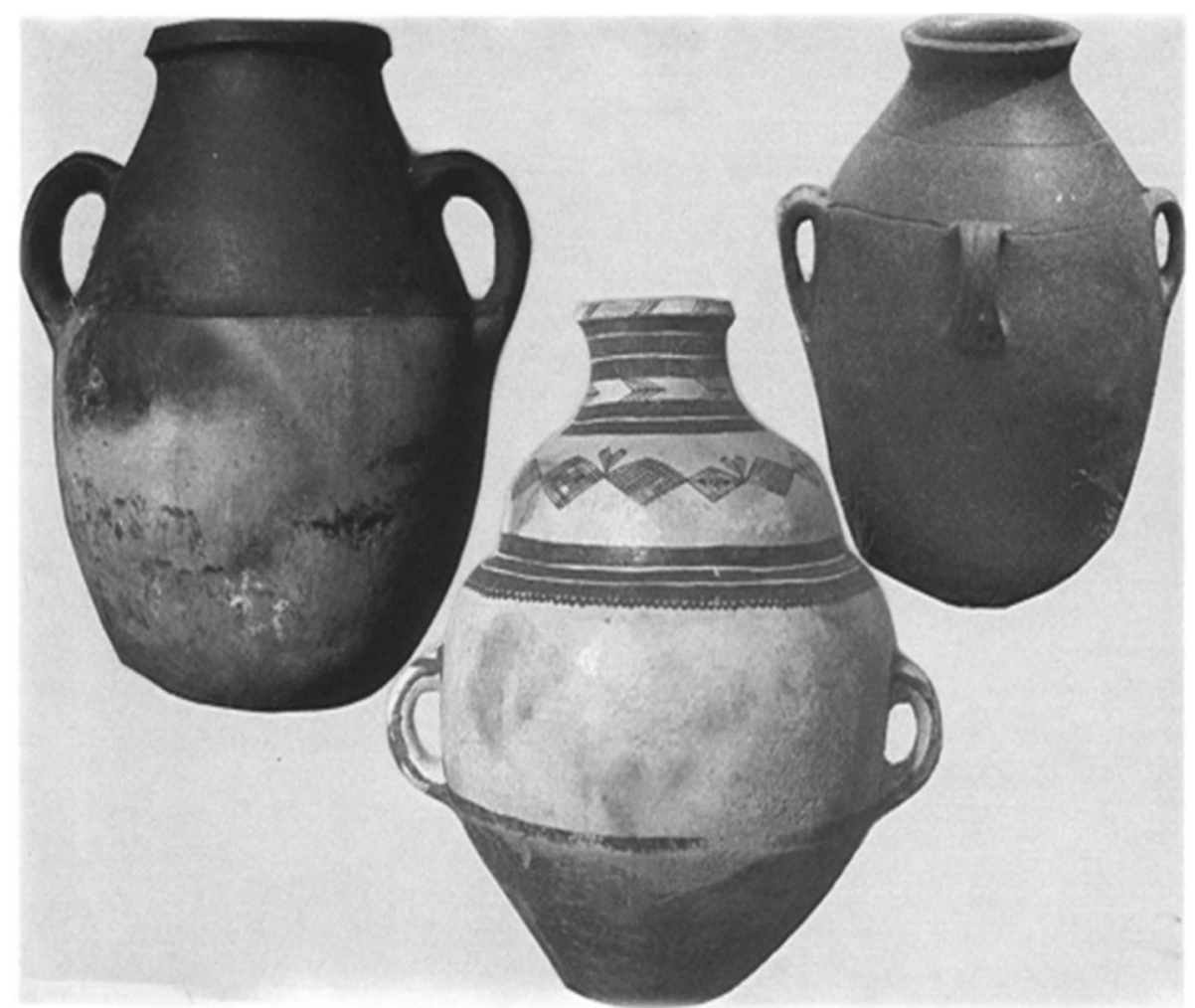

Fig. 8 Curdling vase "Rawaba": during cheese making, raw milk is left to itself in this terracotta pot until it coagulates [21]

spontaneously; the cheese obtained is eaten fresh or after drying [40]. The low-fat cheese separated from "El mis" is spread out to dry in the sun or on the roofing strips of the tents. The dry cheese is kept in dry sheepskins or goatskin called "Mezwed."

\section{Consumption and incorporation of "Klila" cheese into culinary preparations \\ "Klila" cheese consumption by our ancestors}

"Klila" cheese is consumed either fresh or dry. A food survey conducted in villages in the heights of AurèsAlgeria in 1937 showed that milk was consumed in the form of goat milk, "Rayeb" curd, "Lben," dried cheese, and rancid butter. This period of time was marked by under consumption of meat, which was very rarely cooked (but in ritual festivals such as births, circumcisions, and marriages). Protein intake was mainly provided by dairy products and sheep fat used to prepare couscous broths. In the same way, another survey concludes that the food of the rural populations of Aurès remains unchanged for 40 years characterized by a preponderance of cereals, with the consumption of couscous and pancake, and an animal protein malnutrition marked by low intake of meat, however, compensated by fermented milk and dry cheese [21].
Bellakhdar described the dietetics of nomads of the Sahara; as regards diets, they use high-calorie foods, which are easy to keep and available and occupying small volumes to reduce the burden of walkers, children, and riders [20]. They carried objects easily transportable in malleable bags that could support without damage high temperatures. These are dry foods pounded with wood mortar or ground with a stone: cereal grind, dry cheese powder, crushed dates, etc. Foods participate in different preparations that require no cooking. Virtually, all the time, the Berbers use very energetic and low-weight food and know how to make the most of the natural desiccation that their climate operates during the hot season $[20,46]$.

\section{Incorporation of "Klila" cheese in culinary preparations Notion of cheese ingredient}

Over the past decades, cheese has gained increasing commercial importance in the food industry because of its use as a food ingredient. This multipurpose dairy product can be used directly in a range of culinary dishes, formulated food products, and prepared meals [49]. In these applications, it contributes to the structure, texture, flavor, and cooking and/or nutritional properties of food. 
Cheese powders and processed cheeses have traditionally been the main ingredients [50]. Cheese can also be used in the preparation of a set of dehydrated cheese food, including dried cheeses and cheese powders. Compared to natural cheeses, these products are more stable and convenient to use in food formulation and can be designed to provide a wide range of flavor profiles.

\section{Traditional food preparations made from "Klila" cheese}

Berbers' diet came exclusively from the products of their crops and livestock. It consists mainly of primed barley semolina (traditional bread and couscous), dates, and dairy products ("Lben" and dry cheese). Meat is rare and is most often preserved goat meat. Among the Sahara populations, only a few privileged people maintain units or a few small batches of D'men ewes, while the population is totally lacking meat. Dried "Klila" cheese serves then as a substitute for "meat protein" in certain culinary preparations [40]. Dry cheese is made from fresh cheese, rolled into balls and left to dry in the sun. These pellets become as hard as stones. They are put in broth [21]. Dry and crushed "Klila" are mixed with dates, butter, spices, or barley flour [40].
Among the Saharan nomads, "l'aghehara" or "aghgera, " a mixture composed of crushed cheese, ground cereal, "chilli," dates, and water, is very thirst-quenching; in case it is added with churned milk, it is rather called "éghele." "Alakoh" is a drink made of water, date powder, and some cheese powder [21]. To our knowledge and from literature, very little data is available on these last three products. "Klila" cheese is also incorporated into a wide range of traditional culinary preparations; Table 1 summarizes the essential food products based on "Klila."

\section{Similar cheeses to "Klila" in the world}

Several cheeses, similar to the Algerian "Klila" cheese, are made all over the world. "Jameed" is made in many Middle Eastern countries (Jordan, Saudi Arabia, Yemen, Syria, Iraq...), "Chahana" in India and Bangladesh, "Chhuga" (Chhurpi) in Nepal, "Trachanas" in Cyprus, "Kishk" in the Middle East (Qatar, Syria, Egypt and Lebanon), "Muktagachar Monda" in Bangladesh, "Öröm" in Mongolia, "Pastillas De Leche" in the Philippines, "Ayib" in Ethiopia, The "Arish" in Egypt, "Tikkamarin" in Afghanistan, and "Ahaggar" in Niger.

Figure 9 shows the "Jameed" which is made preferably from sheep's milk or goat's milk; it can also be

Table 1 Traditional culinary preparations based on "Klila" cheese

\begin{tabular}{|c|c|}
\hline Traditional culinary preparations & Description \\
\hline Chech h'rire (Assida bougheliya) & Preparation made with fresh Klila, semolina, and cow butter \\
\hline Assida essafra & Egg-based preparation, cow butter, and Klila \\
\hline El aiche (Berkoukess); Chekhchoukha; Berboucha & Traditional pasta with Klila incorporated in red sauce with vegetables \\
\hline Couscous & Fresh Klila is added to the couscous steamed; it gives it a very special taste \\
\hline El merdoud & $\begin{array}{l}\text { Variety of "berkoukess" with herbs, cooked with vegetables, pulses, and Klila } \\
\text { especially intended for pregnant women in southern Algeria }\end{array}$ \\
\hline B'ssissa or Tamina & $\begin{array}{l}\text { Fat and sweet preparation containing butter, honey, and almonds and/or } \\
\text { nuts added with Klila, specially intended for women who have just given } \\
\text { birth in order to favor the secretion of maternal milk }\end{array}$ \\
\hline M' Laoui; Kessra rekhssisse & $\begin{array}{l}\text { A kind of fat traditional bread. Fresh Klila is incorporated into the dough } \\
\text { during hand kneading }\end{array}$ \\
\hline El merdoukh & $\begin{array}{l}\text { Traditional food condiment made with dry Klila, animal fat, salted meat (khlii), } \\
\text { spices, and peppers, made into balls, and used as flavor enhancers for } \\
\text { traditional red pasta sauces }\end{array}$ \\
\hline Ellebri & Whole wheat kernels cooked with dried Klila and chickpeas \\
\hline Imedghess & Milk dessert obtained by a mixture of fresh Klila and fresh milk \\
\hline Edhane el hor & $\begin{array}{l}\text { Rancid butter obtained after washing and brining fresh butter } \\
\text { and added with Klila }\end{array}$ \\
\hline Medghissa & Molten cheese prepared by heating semi dry Klila and whole milk \\
\hline$R^{\prime}$ fiss & $\begin{array}{l}\text { Traditional Algerian cake made from roasted semolina, gherss (crushed dates), } \\
\text { butter, and Klila. It is flattened and cut in lozenges }\end{array}$ \\
\hline Lehrira & Thick soup with vegetables and/or pulses and Klila \\
\hline Lemkartfa & Fine traditional Pasta; Klila is incorporated in the sauce \\
\hline Zri Zri & Traditional cake made from dates, Klila powdered, "edhane el hor," or olive oil \\
\hline B'radjs & $\begin{array}{l}\text { Traditional Algerian cake made from semolina, cow milk, and crushed dates; } \\
\text { Klila is incorporated to the dough and/or gherss }\end{array}$ \\
\hline
\end{tabular}



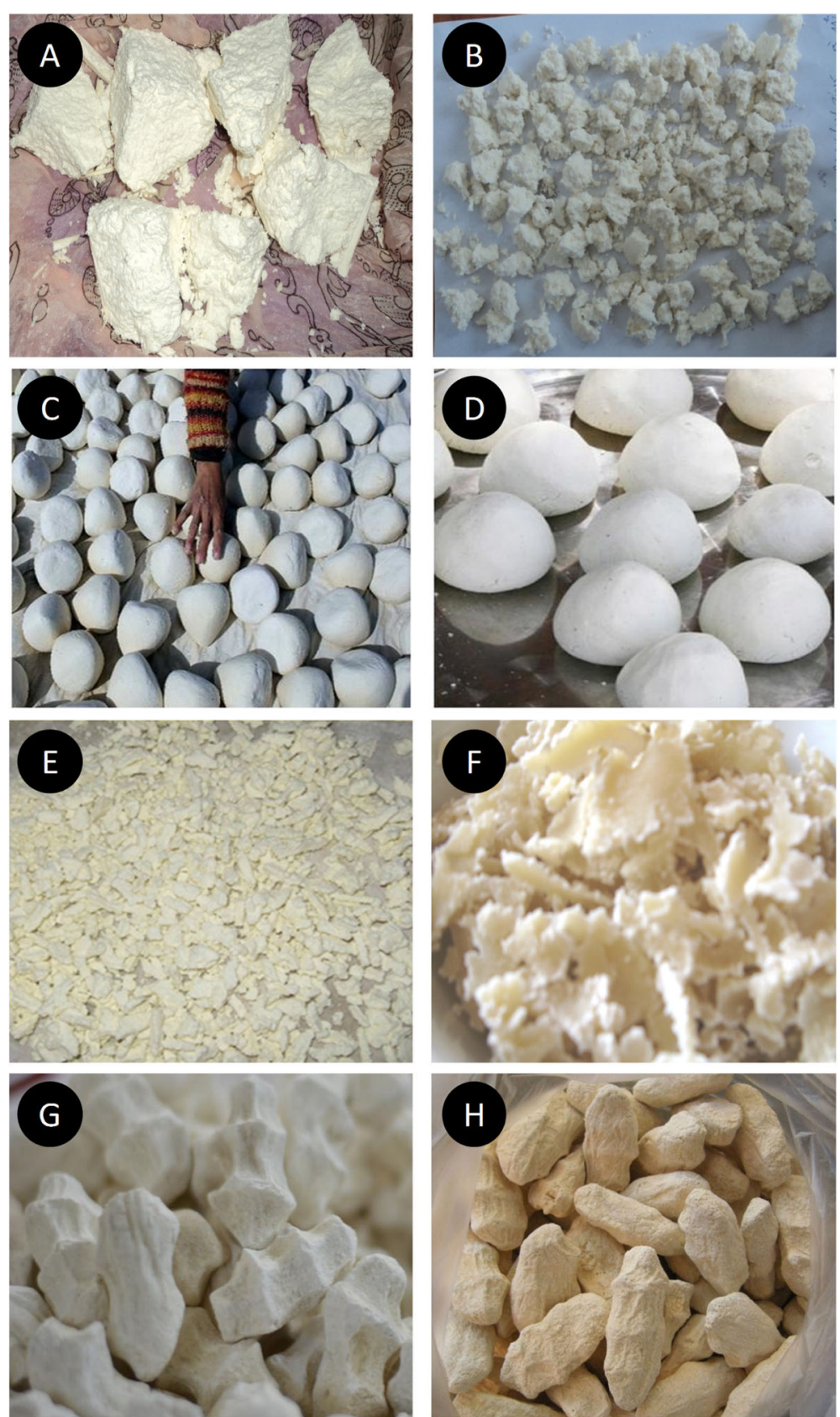

Fig. 9 Some similar cheeses to "Klila" in the world. "Klila" cheese produced from the basic ingredient "Lben" can be consumed fresh (a) or dried (b) especially in festive moments (retrieved from LEKSIR [51]). "Jameed," prepared from the "Lben," by heat treatment, the draining is done on fabric, and the product is salted, kneaded, and then dried in the form of large solid pellets or other forms (c, d) (retrieved from LEKSIR [51]). "Chhurpi" is a cheese product in the mountain area of India, Nepal, and Bhutan made from precipitated proteins buttermilk only or mixed with partly skimmed milk or whole. "Soft chhurpi" contains a high amount of moisture, and thus, it is soft in nature, and it provides instant energy. People generally take it after working hard (e). "Hard chhurpi": the "soft chhurpi" is sun dried for 5 to 7 days as the moisture content becomes low. "Hard chhurpi" is stored for future consumption. Usually, people consume this "chhurpi" with vegetables soup (f) [12]. "Kishk" cheese is made in several Middle Eastern countries and known by different names according to the region. It is called "Hogut" in Qatar, "Kishk" or "Kushk" in Lebanon and Egypt, and "Keshkeh" in Syria. It is made by mixing "Bourghol" (Cereals) and milk, with a progressive addition of "Lben." The "kishk" is mixed with water, salt, garlic, and dried meat then boiled; it is consumed as a hot and pleasant soup ( $\mathbf{g}, \mathbf{h}$ ) (retrieved from LEKSIR [51])

prepared from cow's and camel's milk. It is prepared from the "Lben," by heat treatment; the draining is done on fabric, and the product is salted, kneaded, and then dried in the form of large solid pellets or other forms $[52,53]$. The drying time of the "Jameed" depends on the size, shape, and weather conditions. 
This cheese is manufactured on an industrial scale and is freeze-dried; it is available in large markets in dehydrated and packaged form [52].

"Chhanna" is a cheese that is based on lactic coagulation of milk to recover the curd after whey separation. This cheese is preferentially prepared with cow's milk which gives a cheese with a smooth texture and a sweet taste. Both characteristics are suitable for the production of high-quality "chhanna." Buffalo milk produces a "chhanna" with a slightly hard body and coarse and fat texture [17].

"Chhuga" (chhurpi) is a cheese product in the mountain area of India, Nepal, and Bhutan made from precipitated proteins buttermilk only or mixed with partly skimmed milk or whole. Its shape can be rectangular (7 to $7.5 \mathrm{~cm}$ long, 5.5 to 6.5 wide, and 1 to $3.5 \mathrm{~cm}$ thick) or cubic $(1.5 \mathrm{~cm}$ side, 3.5 to $4 \mathrm{~cm}$ long). In the first case, its weight is $75 \mathrm{~g}$; otherwise, it is about 80 to $100 \mathrm{~g}$. It can also have a pebble shape ( 1 to $2 \mathrm{~cm}$ side), and its weight is in this case 5 to $6 \mathrm{~g}$. It has a strong flavor and smoke. It has a very hard and rubbery appearance, and its dry matter is $92 \%, 81 \%$ protein, and $12.5 \%$ of fat. Cheese making "chhurpi" comprises several steps; the curd is filtered from whey by pressing it, most of the moisture is expelled from soft curd, and then it is put into wooden molds and pressed with stone ballast. After removal of the molds, the curd is cut or broken into smaller pieces that are threaded on a string and be sun-dried or exposed to heat before a fire [12].

"Trachanas" is a cheese produced in Cyprus from sour goat's milk or from a mixture of sheep's and goat's milk and ground wheat. It has a yellowish color and a sour taste. It is an extra hard cheese with a moisture content of 10 to $15 \%$ and 8 to $10 \%$ fat [30]. Goat's milk or a mixture of goat's milk and ewes is acidified for several days either spontaneously or by adding a yogurt culture. It is stirred every day until it reaches the desired acidity. Then, the sour milk is heated and a little ground wheat and salt are added gradually and are mixed to obtain a thick mass which will be heated to boiling. The dough is removed from the heat and allowed to cool, then cut into small finger-sized pieces and dried in the sun. Once dry enough, it is stored in a cool place. This cheese is produced only during the summer and is used to prepare hot soups during the winter [30, 54].

"Kishk" is a cheese similar to "Trachanas" which is made in several Middle Eastern countries and known by different names according to the region. It is called "Hogut" in Qatar, "Kishk" or "Kushk" in Lebanon and Egypt, and "Keshkeh" in Syria [55]. "Kishk" has a dry matter content of 85 to $90 \%$ and fat content of 8 to $10 \%$. It is made by mixing "Bourghol" (cereals) and milk. The mixture is left standing for $24 \mathrm{~h}$ at room temperature.
The next day, the previously prepared "Lben" is added and mixed by hand. Once again, the mixture is left to ferment for $24 \mathrm{~h}$. After 3 days, the whole mixture turns into a pale white paste. This mixture is spread in a thin layer and dried in the sun for about half a day. The "kishk" is mixed with water, salt, garlic, and dried meat then boiled; it is consumed as a hot and pleasant soup. However, this dish is becoming rare nowadays in the Lebanese diet.

"Muktagachar Monda," "Öröm," and "Pastillas De Leche" are hard cheeses with dry matter content respectively of 75 to $80 \%, 75$ to $85 \%$, and $90 \%$, but the manufacturing process differs from that of "Klila" manufacture.

\section{Conclusion}

In Algeria, several traditional cheeses are endangered and deserve special attention. The situation of traditional Algerian dairy products is a reflection of the situation of the dairy sector in the country. It has been in a critical phase for decades confronted with insufficient local raw milk production with a low collection rate. The traditional transformations of milk are partly unknown, partly neglected, and, unfortunately, totally undervalued. On the other hand, the absence of a written history about food in Algeria, the non-transmission and thus the ignorance of the inheritance, the rural exodus, the depreciation of the traditions, and the change of food habits must also be mentioned.

Despite this situation, the potential of the country is huge to promote and completely boost the production of raw milk and therefore the production of traditional cheeses. The country has, in addition to its soil and its Mediterranean-Saharan climate, a rich dairy and cheese tradition as well as a great diversification potential of its milk sources by means of a diversified and complementary breeding between the North and South.

Among the traditionally manufactured products, the category of "fermented milk" and the category of "cheeses" themselves can be distinguished. Apart from certainly fermented milk (Lben and Rayeb) and cheeses (Klila and Jben), which are the best known and geographically the most widespread, all other products have not been the subject of detailed studies.

\section{Acknowledgements \\ The authors thank Dr. Bassim TAZIR (Max Planck Institute, Germany) for his pertinent comments on the manuscript.}

\section{Authors' contributions \\ $\mathrm{CL}$ and SB contributed to the review design, the field survey realization, and analysis, data analysis, and manuscript preparing and writing. NM and MC contributed to the review design, data analysis, and paper redaction. All authors read and approved the final manuscript.}

\section{Funding}

This work is part of the research activity carried out within the "Dairy production: Optimization of production techniques, valorization and quality control" project funded by the Algerian Ministry of Higher Education and Scientific Research, grant agreement no: D00L01UN240120180001. 


\section{Availability of data and materials}

The data that support the findings of this study are available from the corresponding author, Dr. Sofiane BOUDALIA, upon reasonable request.

\section{Competing interests}

The authors declare that they have no competing interest.

\section{Author details}

${ }^{1}$ Faculté des Sciences de la Nature et de la Vie et Sciences de la Terre et de I'Univers, Université 8 Mai 1945 Guelma, BP 4010, 24000 Guelma, Algeria.

2Laboratoire de Biologie, Eau et Environnement, Université 8 Mai 1945 Guelma, BP 4010, 24000 Guelma, Algeria. ${ }^{3}$ Institut National Agronomique de Tunisie (INAT), Tunis, Tunisia.

\section{Received: 30 April 2019 Accepted: 22 August 2019} Published online: 02 September 2019

\section{References}

1. Shori AB. Camel milk and its fermented products as a source of potential probiotic strains and novel food cultures: a mini review. PharmaNutrition. 2017:5(3):84-8

2. Boudalia S, Benati D, Boukharouba R, Chemakh B, Chemmam M. Physicochemical properties and hygienic quality of raw and reconstituted milk in the region of Guelma-Algeria. International Journal of Agricultural Research. 2016;11(2):77-83.

3. Bousbia A, Boudalia S, Chelia S, Oudaifia K, Amari H, Benidir M, et al. Analysis of factors affecting consumer behavior of dairy products in Algeria: a case study from the region of Guelma. International Journal of Agricultural Research. 2017:12(2):93-101.

4. Leksir C, Chemmam M. Contribution on the characterization of Klila, a traditional cheese in east of Algeria. Livestock Research for Rura Development. 2015;27:5

5. Benamara RN, Gemelas L, Ibri K, Moussa-Boudjemaa B, Demarigny $Y$. Sensory, microbiological and physico-chemical characterization of Klila, a traditional cheese made in the south-west of Algeria. African Journal of Microbiology Research. 2016;10(41):1728-38.

6. Benlahcen K, Mahamedi AE, Djellid Y, Sadeki IF, Kihal M. Microbiological characterization of Algerian traditional cheese "Klila". Journal of purity, utility, reaction and environment. 2017:6(1):1-9.

7. Mennane Z, Khedid K, Zinedine A, Lagzouli M, Ouhssine M, Elyachioui M. Microbial characteristics of Klila and Jben traditionnal Moroccan cheese from raw cow's milk. World Journal of Dairy \& Food Sciences. 2007;2(1):23-7.

8. Guetouache M, Guessas B. Characterization and identification of lactic acid bacteria isolated from traditional cheese (Klila) prepared from cow's milk. African Journal of Microbiology Research. 2015;9(2):71-7.

9. Fox PF, McSweeney PLH. Cheese: an overview. In: Fox PF, McSweeney PLH, Cogan TM, Guinee TP, editors. Cheese: Chemistry, Physics and Microbiology: Academic Press; 2004. p. 1-18.

10. Vilain AC. Qu'est-ce que le lait? Revue française d'allergologie. 2010;50(3):124-7.

11. Shetty K, Paliyath G, Pometto A, Levin RE. In: Press C, editor. Food biotechnology. 2nd ed: Taylor \& Francis; 2006. p. 1982.

12. Panda A, Ghosh K, Ray M, Nandi SK, Parua S, Bera D, et al. Ethnic preparation and quality assessment of Chhurpi, a home-made cheese of Ladakh, India. Journal of Ethnic Foods. 2016;3(4):257-62.

13. Bargis P. Le grand livre des aliments santé. Paris: Groupe Eyrolles; 2012.

14. Corrieu G, Luquet F. Bactéries lactiques, de la génétique aux ferments. Paris; 2008

15. Rai R, Shangpliang HNJ, Tamang JP. Naturally fermented milk products of the Eastern Himalayas. Journal of Ethnic Foods. 2016:3(4):270-5.

16. Claps S, Morone G. Produits laitiers et fromagers traditionnels de l'Algérie; 2011.

17. McSweeney PLH, Ottogalli G, Fox PF. Chapter 31 - Diversity and classification of cheese varieties: an overview. In: McSweeney PLH, Fox PF, Cotter PD, Everett DW, editors. Cheese. Fourth ed. San Diego: Academic Press; 2017. p. 781-808.

18. Benkerroum N, Tamime AY. Technology transfer of some Moroccan traditional dairy products (lben, jben and smen) to small industrial scale. Food Microbiology. 2004:21(4):399-413.

19. Benkerroum N. Traditional fermented foods of North African countries: technology and food safety challenges with regard to microbiological risks. Comprehensive Reviews in Food Science and Food Safety. 2013;12:54-89.
20. Bellakhdar J. Hommes et plantes au Maghreb : éléments pour une méthode en ethnobotanique. 1st edition ed. Plurimondes, editor. Maroc. 2008. 386 p.

21. Chaker S. Amaziy (le/un Berbère). In: Edisud, editor. Alger - Amzwar. Gabriel Camps. 1986. Available from: http://journals.openedition.org/ encyclopedieberbere/2465

22. FAO. The technology of traditional milk products in developing countries. Rome: Food and Agricultural Organization of the United Nations; 1990. p. 333.

23. Tantaoui-Elaraki A, El Marrakchi A. Study of Moroccan dairy products: Iben and smen. MIRCEN journal of applied microbiology and biotechnology. 1987;3(3):211-20.

24. Kacem M, Karam NE. Physicochemical and microbiological study of "shmen", a traditional butter made from camel milk in the sahara (Algeria): isolation and identification of lactic acid bacteria and yeasts. Grasas y Aceites. 2006; 57(2):198-204

25. Licitra G, Caccamo M, Lortal S. Chapter 9 - Artisanal products made with raw milk. In: Nero LA, De Carvalho AF, editors. Raw Milk: Academic Press; 2019. p. 175-221.

26. Mechai A, Debabza M, Kirane D. Screening of technological and probiotic properties of lactic acid bacteria isolated from Algerian traditional fermented milk products. International Food Research Journal. 2014:21(6):2451-7.

27. Jans C, Meile L, Kaindi DWM, Kogi-Makau W, Lamuka P, Renault P, et al. African fermented dairy products - overview of predominant technologically important microorganisms focusing on African Streptococcus infantarius variants and potential future applications for enhanced food safety and security. International Journal of Food Microbiology. 2017;250:27-36.

28. El Rhazi K, Garcia-Larsen V, Nejjari C. Chapter 12 - Socioeconomic factors affecting adherence to the Mediterranean diet in North Africa. In: Preedy VR, Watson RR, editors. The Mediterranean Diet. San Diego: Academic Press; 2015. p. 123-32

29. Tantaoui-Elaraki A, Berrada M, El Marrakchi A, Berramou A. Etude sur le Lben marocain. Le Lait, INRA Editions. 1983;63:230-45.

30. Anagnostopoulos DA, Tsaltas D. Chapter 10 - fermented foods and beverages. In: Galanakis CM, editor. Innovations in Traditional Foods: Woodhead Publishing; 2019. p. 257-91.

31. Harrati E. Recherches sur le Lben et le Klila algériens: Université de Caen (France); 1974.

32. Samet-Bali O, Bellila A, Ayadi M-A, Marzouk B, Attia H. A comparison of the physicochemical, microbiological and aromatic composition of Traditional and Industrial Leben in Tunisia. International Journal of Dairy Technology. 2010;63(1):98-104

33. El Galiou O, Zantar S, Bakkali M, Laglaoui A, Centeno JA, Carballo J. Chemical and microbiological characteristics of traditional homemade fresh goat cheeses from Northern Morocco. Small Ruminant Research. 2015;129:108-13.

34. McSweeney PLH, Ottogalli G, Fox PF. Diversity of cheese varieties: an overview. In: Fox PF, McSweeney PLH, Cogan TM, Guinee TP, editors. Cheese: Chemistry, Physics and Microbiology: Academic Press; 2004. p. 1-23.

35. Ouadghiri M, Amar M, Vancanneyt M, Swings J. Biodiversity of lactic acid bacteria in Moroccan soft white cheese (Jben). FEMS Microbiology Letters. 2005;251(2):267-71.

36. Hayaloglu AA. Chapter 39 - Cheese varieties ripened under brine. In: McSweeney PLH, Fox PF, Cotter PD, Everett DW, editors. Cheese. Fourth ed. San Diego: Academic Press; 2017. p. 997-1040.

37. Derouiche M, Zidoune MN. Characterization of a traditional Michouna cheese from the region of Tébessa, Algeria. Livestock Research for Rural Development. 2015;27:11.

38. Adewumi GA. Health-promoting fermented foods. In: Melton L, Shahidi F, Varelis P, editors. Encyclopedia of Food Chemistry. Oxford: Academic Press; 2019. p. 399-418.

39. Ramalho Ribeiro JMC, Horta AEM, Mosconi C, Rosati A. Animal products from the Mediterranean area. Series ES; 2006.

40. Ben Danou C. QUEL QUES NOTES DE LAITERIE SUR L'ALGÉRIE. Le Lait, INRA Editions. 1929;9(82):161-163.

41. Aissaoui Zitoun O, Benatallah L, Ghennam E-H, Zidoune MN. Manufacture and characteristics of the traditional Algerian ripened bouhezza cheese. J Food Agric Environ. 2011:9:96-100

42. Aissaoui Zitoun O, Pediliggieri C, Benatallah L, Lortal S, Licitra G, Zidoune $M N$, et al. Bouhezza, a traditional Algerian raw milk cheese, made and ripened in goatskin bags. J Food Agric Environ. 2012;10:289-95. 
43. Medjoudj H, Aouar L, Zidoune MN, Hayaloglu AA. Proteolysis, microbiology, volatiles and sensory evaluation of Algerian traditional cheese Bouhezza made using goat's raw milk. International Journal of Food Properties. 2017; 20(sup3):S3246-S65.

44. Medjoudj H, Zidoune MN, Hayaloglu AA. Proteolysis and volatile profile in the Algerian traditional Bouhezza cheese made using raw goat's milk. International Journal of Food Properties. 2017;20(8):1876-93.

45. Khoualdi G. Caractérisation du fromage traditionnel algérien «Medeghissa». I.N.A.T.A.A. Constantine: Université de Constantine 1 2017. Available from: https://bu.umc.edu.dz/theses/agronomie/KHO7145.pdf.

46. Denis P. L'Harmattan, editor. Les derniers nomades, vol. 631. p. Paris1989.

47. Bachtarzi N, Kharroub K, Ruas-Madiedo P. Exopolysaccharide-producing lactic acid bacteria isolated from traditional Algerian dairy products and their application for skim-milk fermentations. LWT. 2019;107:117-24.

48. Grappin R, Coulon JB. "Terroir", milk and cheese production: some comments. Renc Rech Ruminants. 1996. p. 21-28. Available from: http:// www.journees3r.fr/IMG/pdf/1996_1_territoire_03_grappin.pdf.

49. Guinee TP, Kilcawley KN. Cheese as an ingredient. In: Fox PF, McSweeney PLH, Cogan TM, Guinee TP, editors. Cheese: Chemistry, Physics and Microbiology: Academic Press; 2004. p. 395-428.

50. Lucey JA. Some perspectives on the use of cheese as a food ingredient. Dairy Sci Technol. 2008;88:573-94

51. LEKSIR C. Caractérisation, fabrication et consommation du dérivé laitier traditionnel «Klila » dans l'Est Algérien [Characterization, production and consumption of the traditional milk derivative "Klila" in eastern Algeria]: 8 Mai 1945 Guelma, Algeria; 2018

52. Abu-Lehia IH. The chemical composition of jameed cheese. Ecology of Food and Nutrition. 1988;20(3):231-9.

53. Al-Ismail KM, Herzallah SM, Humied MA. Effect of processing and storage of Jameed on conjugated linoleic acid content and fat and cholesterol oxidation. LWT - Food Science and Technology. 2007;40(3):454-9.

54. Papachristoforou C, Markou M. Overview of the economic and social importance of the livestock sector in Cyprus with particular reference to sheep and goats. Small Ruminant Research. 2006;62(3):193-9.

55. Tamime AY, O'Connor TP. Kishk — a dried fermented milk/cereal mixture. International Dairy Journal. 1995;5(2):109-28.

\section{Publisher's Note}

Springer Nature remains neutral with regard to jurisdictional claims in published maps and institutional affiliations.

Ready to submit your research? Choose BMC and benefit from:

- fast, convenient online submission

- thorough peer review by experienced researchers in your field

- rapid publication on acceptance

- support for research data, including large and complex data types

- gold Open Access which fosters wider collaboration and increased citations

- maximum visibility for your research: over $100 \mathrm{M}$ website views per year

At $\mathrm{BMC}$, research is always in progress.

Learn more biomedcentral.com/submissions 